\title{
E-LEARNING COURSE IN SMART TEXTILES
}

\author{
Ion Razvan Radulescu ${ }^{1}$, Luis Almeida ${ }^{2}$, Benny Malengier ${ }^{3}$, Zoran Stjepanovic ${ }^{4}$, \\ Mirela Blaga ${ }^{5}$ and Petra Dufkova ${ }^{6}$ \\ ${ }^{1}$ INCDTP - Bucharest, Str. L. Patrascanu 16, Bucharest, Romania \\ ${ }^{2}$ University of Minho / TecMinho, Campus de Azurem, Guimaraes, Portugal \\ ${ }^{3}$ Ghent University, Technologiepark-Zwijnaarde 70A, Ghent, Belgium \\ ${ }^{4}$ University of Maribor, Smetanova 17, Maribor, Slovenia \\ ${ }^{5}$ Technical University of Iasi, Str. D. Mangeron 29, Iași, Romania \\ ${ }^{6}$ Textile Testing Institute - TZU, Cejl 480/12, Brno, Czech Republic
}

\begin{abstract}
E-learning offers multiple benefits for learners and is especially compatible with STEM fields. Smart textiles are a modern trend of the textile domain and represents a multi-disciplinary field. Smart textiles are used to showcase an end-application of STEM fields for VET students, within the Erasmus+ project Skills4Smartex. A course of 28 theoretical (STEM to Smart) modules and 28 practical modules (Smart to STEM) was achieved, by combining seven chapters of textile technology with each of the four modules of basic STEM disciplines: Mathematics, Physics, Material science - Chemistry and Electrotechnics. A Moodle e-learning course in weekly format was created for each national language of the project - Czech, Dutch, Portuguese, Romanian, Slovenian and English. The e-learning course includes an embedded SWF presentation of each of the theoretical modules in national language, a Book resource and a Quiz activity of each of the theoretical modules in English, as well as a Chat activity of communication between tutor and trainee. Blended courses are envisaged for the ongoing Skills4Smartex project during autumn 2020. For the pandemic restrictions period (March-May 2020), educational resources achieved in previous Erasmus+ projects were offered with Guest access for students and 214 access sessions were registered. The proposed educational approach combines smart textiles prototypes construction and related educational modules from theory to practice and from prototypes to theory, available as Open Educational Resources in e-learning format.
\end{abstract}

\section{KEYWORDS}

Vocational Education and Training, Basic Disciplines, Smart Textiles

\section{INTRODUCTION}

E-learning may be introduced in various fields of education (Grosseck G., Malita, L, 2015). It may serve as instrument for primary school teaching, humanistic sciences, creative and show arts and STEM (Science, Technology, Engineering and Mathematics) fields (Radulescu, I. R., Almeida, L., Stjepanovic, Z. et al, 2017). E-learning is especially applicable with STEM fields, due to rigorous structuring of content, compatibility with informatics instruments and possibility to show multimedia content on technologies (Radulescu, I. R, Ghituleasa, C.; Visileanu, E. at al, 2018). Textile technology is a multi-disciplinary field, combining several STEM fields, such as: material science and chemistry, mathematics, physics, electronics, informatics, mechanics and mechatronics etc (Dodu A, 2005). Smart textiles represent a modern trend in the textile field, consisting of textile materials that are able to sense stimuli from the environment, to react to them and adapt to them by integration of functionalities in the textile structure (Van Langenhove L., 2013). Moreover, smart textiles may include for these functionalities components such as: sensors, data processing, actuators, energy storage and communication (Malengier B., Tseghai G.B., Van Langenhove L. et al., 2019).

The preparation of technical VET (Vocational Education and Training) students in the last two years of high school and in first two years of college means acquiring of a high amount of theoretical basic disciplines, such as: mathematics, physics, chemistry-material science, electrotechnics. Mathematical relations such as integrals or derivative for physics and engineering remain often theory without an end-application horizon for the students. The link between theory and praxis for the future technician and 
engineer has to be made by showcasing end applications of basic disciplines. Smart textiles is a suitable topic for this purpose: they combine various basic disciplines and they represent applications of the acquired knowledge.

Thus, VET is needed to complete the current learning curricula in high schools and colleges. By providing smart textiles prototypes examples, both in a do-it-yourself (DIY) approach and in an explanatory approach (by means of educational modules), students may integrate acquired knowledge in a broader view of end-applications. Current educational approaches are oriented either practical or theoretical, either in classroom or e-learning format.

Main aim of this study is to provide a comprehensive educational approach, with smart textiles prototypes construction and related educational modules from theory to practice and from prototypes to theory, available as Open Educational Resources in e-learning format.

\section{THE SKILLS4SMARTEX PROJECT}

The Erasmus+ VET project "Smart textiles for STEM training" tackles this rationale. It is an ongoing project with the duration of two years (2018-2020), involving a prestigious consortium of educational providers in textiles: The National R\&D Institute for Textiles and Leather - Bucharest, TecMinho / University of Minho Portugal, Ghent University - Belgium, University of Maribor - Slovenia, Technical University of Iasi and the Textile Testing Institute of Czech Republic. More info on the project's website: www.skills4smartex.eu.

The project's partners have developed educational modules in the field of smart textiles in relation to the basic disciplines, such as: mathematics, physics, material science - chemistry and electrotechnics. The educational modules are divided mainly in two directions: from theory to praxis (STEM to Smart) and from practice to theory (Smart to STEM). The modules of Smart to STEM direction present achieved smart textile prototypes (Figure 1).
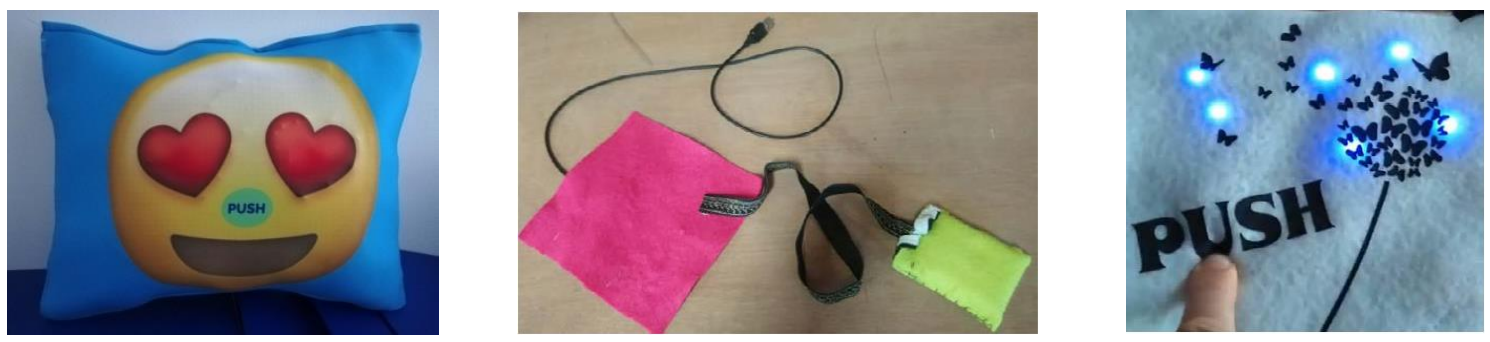

Figure 1. Manufactured smart textiles prototypes for educational purposes

This approach is meant to highlight for the VET students in technical disciplines, some end-application of basic disciplines they are learning. Further on, the modules are divided on seven chapters of textile technology, meant to follow the production chain of smart textiles: Novel fibers and yarns, materials and methods, virtual prototyping for sensors on smart textiles, smart textile design, smart textile prototypes, data processing and new methods for testing smart textiles. As such, it results in a total number of 56 modules: two directions (relation between STEM and Smart) multiplied with seven chapters of textile technology and with the four basic disciplines. A dedicated e-learning instrument was programmed in PHP in order to access all these modules via a filter, freely accessible online via the URL address: www.skills4smartex.eu/instrument.php. (Radulescu I R, Ghituleasa C, Visileanu E., et al, 2020) However, this paper focuses on the Skills4Smartex Moodle e-learning course developed on the project's e-learning platform www.advan2tex.eu/portal/. Since due to pandemic restrictions no face-to-face valorization of the achieved educational modules could be performed yet, the project was prolonged with three months and organization of blended courses is planned for autumn 2020. However, existing e-learning resources were provided with free access (Guest access). 


\section{THE E-LEARNING COURSE}

The Moodle e-learning platform was configured within a first Erasmus+ VET project Advan2Tex, www.advan2tex.eu. The e-learning platform includes the Open Educational Resources (OER) of three Erasmus+ VET projects: Advan2Tex (2014-2016), TexMatrix (2016-2018) and the ongoing project Skills4Smartex (2018-2020). The courses of the first two projects are available online with Guest access (Figure 2).

\section{E-learning for textiles}
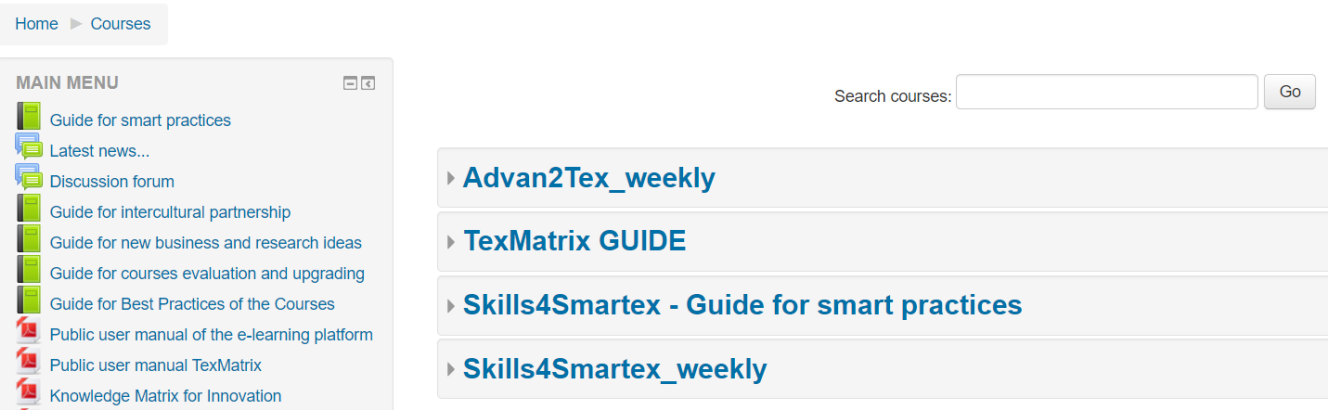

Figure 2. The e-learning courses of the three projects (www.advan2tex.eu/portal/)

The Moodle e-learning course of Skills4Smartex is meant for blended courses training of VET students of high schools and colleges of technical domains. Blended courses are a mixed form of classroom and e-learning courses according to the Erasmus+ Programme Guide (Erasmus+, 2020). Classroom courses are expected to train students with smart textiles prototypes do-it-yourself methods, while the e-learning courses will support the trainees with the needed online resources. This blended type of course has multiple benefits, for it combines face-to-face explanations of tutors and offers the OER in a modern format for distance access.

The Skills4Smartex e-learning course category includes six courses in national languages of the partner's countries organizations - Czech, Dutch, Portuguese, Romanian, Slovenian - and English. Each course is conceived in weekly format: the seven chapters are divided over three weeks of lesson plans. The first week includes the chapters: Novel fibers and yarns and Materials and methods; the second week includes: Virtual prototyping for sensors on smart textiles, Smart textile design and Smart textile prototypes, while the third week includes: Data processing and New methods for testing smart textiles. Each chapter includes the 4 modules of basic technical disciplines: Mathematics, Physics, Material science and chemistry and Electrotechnics. The following Moodle activities and resources were created for each module:

- One Presentation in national language

- One Book resource with the module in English

- One Quiz activity with 15-20 multiple choice questions on the module in English

- One Chat activity for synchronous communication between tutor and trainee per week

As such, a print screen of the course in English is presented in Figure 3.

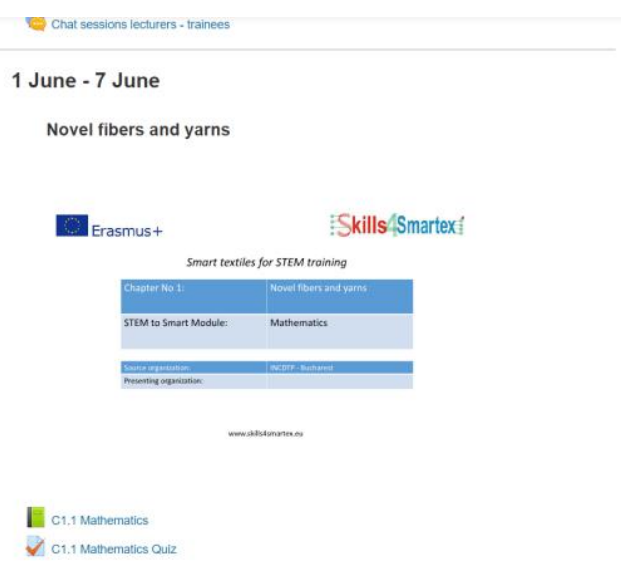

Figure 3. Print screen of the e-learning course structure 
The presentation is originally a PPT file, which was transformed into SWF file and implemented within the course page as Moodle Label resource, by modifying the HTML code. This solution provides interactive and quick access to the resources in national language. Table 1 presents the applied e-learning implementation solutions for adapting the educational content to the target group, in an attractive and practical manner.

Table 1. Solutions to implement the educational content into e-learning resources

\begin{tabular}{|c|c|c|}
\hline Educational content & E-learning solution & Technical data \\
\hline $\begin{array}{l}\text { Asynchronous } \\
\text { communication }\end{array}$ & $\begin{array}{l}\text { Forum for general } \\
\text { questions and } \\
\text { answers }\end{array}$ & $\begin{array}{l}\text { Forum is meant for questions of } \\
\text { trainees for tutors regarding content of } \\
\text { the course }\end{array}$ \\
\hline $\begin{array}{l}\text { Synchronous } \\
\text { communication }\end{array}$ & $\begin{array}{l}\text { Chat sessions } \\
\text { lecturers - trainees }\end{array}$ & $\begin{array}{l}\text { Once per week on Thursday for one } \\
\text { hour for on spot clarifications } \\
\text { regarding the course }\end{array}$ \\
\hline $\begin{array}{l}\text { Module content in } \\
\text { national language }\end{array}$ & $\begin{array}{l}\text { Embedded SWF } \\
\text { presentation }\end{array}$ & $\begin{array}{l}\text { The PPT of the module was } \\
\text { transformed into SWF and } \\
\text { implemented as label in the course }\end{array}$ \\
\hline $\begin{array}{l}\text { Module content in } \\
\text { English }\end{array}$ & $\begin{array}{l}\text { Moodle Book } \\
\text { resource }\end{array}$ & $\begin{array}{l}\text { The content of the module (text, } \\
\text { images) was implemented as Book } \\
\text { (navigation bars, table of contents) }\end{array}$ \\
\hline $\begin{array}{l}\text { Multiple choice } \\
\text { questions in English }\end{array}$ & $\begin{array}{l}\text { Moodle Quiz } \\
\text { activity }\end{array}$ & $\begin{array}{l}\text { The } 15-20 \text { questions per module were } \\
\text { implemented via Aiken format (total } \\
\text { of } 420 \text { questions) }\end{array}$ \\
\hline
\end{tabular}

These e-learning resources are meant for the blended courses to be organized by the project's partners in autumn 2020. Some of the OERs provided by the e-learning platform were used during pandemic restrictions in the time interval March-May 2020 too. As such, 8 trainees from the Technical University "Gh. Asachi" from Iasi - Faculty of Industrial Design and Management, were assigned to the e-learning course of Advan2Tex project, which includes following modules: advanced knitting technology; virtual prototyping of garments; textile testing; standardization; sustainability, LCA and eco-labelling; entrepreneurship and innovation management. The interest of the trainees was focused on advanced textile technologies. Moreover, the e-learning courses were provided with Guest access for the University of Oradea - Faculty of Energy Engineering and Industrial Management - Department of Textiles, Leather and Industrial Management and University "Aurel Vlaicu" of Arad - Faculty of Engineering - Department of Spinning and Weaving. During the pandemic a total number of 214 accesses sessions of the course were registered.

\section{CONCLUSION}

This paper presents an e-learning implementation contribution for a course of STEM fields' application by means of smart textiles. The multi-disciplinarily of smart textile manufacturing showcases end-applications for Mathematics, Physics, Material science - Chemistry and Electrotechnics. A total number of 56 modules were accomplished on two directions (from theory to practice and vice-versus). The implemented solutions envisage an embedded SWF presentation, a Book resource and a Quiz activity for each of the 28 theoretical modules (STEM to Smart direction). Presentations are in national languages (CZ, DU, PT, RO, SI), while Book resources and Quiz activities are in English language. This concept of the e-learning course is tailored with the educational content achieved and sets the premises of attractive and useful blended courses, to be organized in autumn 2020. During the pandemic restrictions (March-May 2020), the available OER courses on the e-learning platform (www.advan2tex.eu/portal/) were offered with Guest access. A total number of 214 access sessions were registered during this period, with focus on the Advan2Tex (2014-2016) course on innovative textile fields. 


\section{ACKNOWLEDGEMENT}

This project has been funded with support of the European Commission. The European Commission's support for the production of this publication does not constitute an endorsement of the contents, which reflect the views only of the authors, and the Commission cannot be held responsible for any use which may be made of the information contained therein. Publishing has been funded by Ministry of Research and Innovation, by Program 1 - Development of the national system for R\&D, Subprogram 1.2 - Institutional performance - projects for funding excellence in R\&D\&I, contract no. 6PFE from 16.10.2018.

\section{REFERENCES}

Dodu A. (coordinator), 2005, Handbook of the Textile Engineer, AGIR Publishing, Bucharest, Romania

Erasmus+ Programme Guide, online resource: https://ec.europa.eu/programmes/erasmus-plus/resources/programmeguide_en , accessed May, 2020

Grosseck G., Malita, L, 2015. Guide for best practices E-learning, West University Publishing, Timisoara, Romania.

Malengier B., Tseghai G.B., Van Langenhove L. et al., 2019, Functional Shoe for the Detection of Walking Pattern Anomalies, ITMC 2019 International Conference on Intelligent Textiles and Mass Customisation, Marrakech, Morocco

Radulescu, I. R., Almeida, L., Stjepanovic, Z. et al, 2017, E-learning in advanced textiles, Industria textila scientific magazine, vol. 68 , no. 3 , pp. 226-231

Radulescu, I. R, Ghituleasa, C.; Visileanu, E. at al, 2018, Benchmarking evaluation of innovation in textile enterprises, ELSE 2018 international scientific conference e-learning and software for education, Bucharest, Romania, pp. 194-199

Radulescu I R, Ghituleasa C, Visileanu E., et al, 2020, Dedicated e-learning instrument to support STEM knowledge by means of smart textiles, ELSE 2020 international scientific conference e-learning and software for education, Bucharest, Romania, pp. 339-345

Van Langenhove L., 2013, Smart textiles for protection - Part I - An Overview, Woodhead Publishing Limited, Cambridge, UK 